\title{
EFFECT OF A SINGLE DOSE OF HUMAN CHORIONIC GONADOTROPHIN ON THE OVULATORY RESPONSE OF THE IMMATURE RAT
}

\author{
SHICHIRO SUGAWARA, MOTOAKI UMEZU \\ AND SABURO TAKEUCHI \\ Department of Animal Husbandry, Faculty of Agriculture, \\ Tohoku University, Sendai, Japan
}

(Received 14th February 1969, revised 27th May 1969)

It has been reported that a single dose of human chorionic gonadotrophin (HCG) is capable of inducing ovulation within $24 \mathrm{hr}$ in a variety of adult rodents and in the rabbit when administered in late di-oestrus or oestrus (Saunders, 1947; Mitchell \& Yochim, 1968), in pregnancy (Burdick \& Ciampa, 1944; Rowlands, 1956; Greenwald, 1964, 1966, 1967; Adams, 1968) and during lactation (Greenwald, 1965). The purpose of the present experiments was to determine whether a single injection of HCG would induce ovulation in the immature rat.

The Wistar strain of rats, aged 19 to 31 days at the beginning of treatment, was used and the animals were kept in an air-conditioned room, the temperature was $25 \pm 1.0^{\circ} \mathrm{C}$ with $12 \mathrm{hr}$ light and $12 \mathrm{hr}$ of darkness.

The first experiment was carried out on the time relationship between the administration of HCG and the occurrence of ovulation. The 25-day-old rats were given a single subcutaneous injection (20 i.u.) of HCG (Puberogen; Tomoda Ltd) between 09.30 and 10.30 hours. After 24, 48, 72 and $96 \mathrm{hr}$, the animals were killed and examined for evidence of ovulation. In addition, the number of corpora lutea and large (pre-ovulatory) follicles were recorded. If ova were present in the tubes, they were counted under a dissecting microscope at a magnification of $\times 40$, by gently pressing the oviduct between two slides. A control group of adult rats in late di-oestrus was also included. The proportions of animals which had ovulated $24 \mathrm{hr}$ and $72 \mathrm{hr}$ after HCG treatment were $40 \%$ and $100 \%$, respectively. The number of shed ova $24 \mathrm{hr}$ after HCG was considerably below that expected at natural oestrus or that observed after $72 \mathrm{hr}$ (Table 1). All rats in which vaginal opening was observed $72 \mathrm{hr}$ after HCG treatment were found to have ovulated. In the 48-hr group, it was found that six animals had a mean of 2.4 corpora lutea which might have resulted from ovulated or haemorrhagic follicles which had been induced by the HCG. In addition, in two of the twelve animals, eggs were present in the middle of the oviduct. These findings suggest that the six animals ovulated within $24 \mathrm{hr}$ of HGG administration. It was also observed that, in all of the animals killed at $48 \mathrm{hr}$ after HCG, the uterus was filled with fluid as in the adult rat at pro-oestrus.

In the 96-hr group, ovulation occurred in all the animals. However, the eggs 
were now found in the middle of the tube, indicating that ovulation occurred within $72 \mathrm{hr}$ of HCG.

It is interesting that either HCG alone or PMSG alone (McCormack \& Meyer, 1962, 1968; Umezu, Kodama \& Takeuchi, 1968) can induce ovulation in the immature rat $72 \mathrm{hr}$ after treatment.

TABLE 1

EFFECTS OF HCG (20 I.U.) ON THE OVULATORY RESPONSE OF RATS AGED 25 DAYS

\begin{tabular}{|c|c|c|c|c|c|c|c|}
\hline \multirow{2}{*}{$\begin{array}{c}\text { Autopsy } \\
\text { (hr after } \\
H C G)\end{array}$} & \multirow[b]{2}{*}{$\begin{array}{l}\text { No. of } \\
\text { animals }\end{array}$} & \multirow{2}{*}{$\begin{array}{c}\text { Mean } \\
\text { body weight } \\
(\mathrm{g})\end{array}$} & \multirow{2}{*}{$\begin{array}{c}\text { No. of } \\
\text { ovulated } \\
\text { animals }\end{array}$} & \multicolumn{2}{|c|}{ Ovulation } & \multirow[b]{2}{*}{$\begin{array}{l}\text { Position } \\
\text { of ova }\end{array}$} & \multirow[b]{2}{*}{$\begin{array}{l}\text { Vaginal } \\
\text { opening }\end{array}$} \\
\hline & & & & $\%$ & $\begin{array}{c}\text { No. of ova } \\
(\text { mean } \pm \text { S.E. }\end{array}$ & & \\
\hline $\begin{array}{c}24 \\
48 \\
72 \\
96 \\
24 \\
\text { (adult) } \dagger\end{array}$ & $\begin{array}{l}10 \\
12 * \\
10 \\
12 \\
7\end{array}$ & $\begin{array}{r}62 \\
66 \\
69 \\
73 \\
230\end{array}$ & $\begin{array}{r}4 \\
2 \\
10 \\
12 \\
7\end{array}$ & $\begin{array}{r}40 \\
17 \\
100 \\
100 \\
100\end{array}$ & $\begin{array}{r}2 \cdot 5 \pm 0 \cdot 9 \\
1 \cdot 0 \pm 0 \cdot 0 \\
9 \cdot 3 \pm 0 \cdot 6 \\
8 \cdot 6 \pm 0 \cdot 5 \\
12 \cdot 6 \pm 0 \cdot 3\end{array}$ & $\begin{array}{l}\text { Ampulla } \\
\text { Middle of ampulla } \\
\text { Middle of ampulla } \\
\text { Middle of oviduct } \\
\text { Ampulla }\end{array}$ & $\begin{array}{l}- \\
- \\
+ \\
+\end{array}$ \\
\hline
\end{tabular}

* Six of twelve animals had haemorrhagic follicles or fresh corpora lutea. The mean number of corpora lutea was $2 \cdot 4 \pm 0 \cdot 6$.

$\dagger$ HCG was administered in late di-oestrus.

TABLE 2

EFFECT OF HGG (20 I.U.) ON THE OVULATORY RESPONSE OF IMMATURE RATS, AGED 19 to 31 DAYS

\begin{tabular}{|c|c|c|c|c|c|c|c|c|}
\hline \multirow[b]{2}{*}{ Group } & \multirow{2}{*}{$\begin{array}{c}\text { Age at } \\
\text { treatment } \\
\quad(\text { day }\rangle\end{array}$} & \multirow[b]{2}{*}{$\begin{array}{l}\text { No. of } \\
\text { animals }\end{array}$} & \multirow{2}{*}{$\begin{array}{c}\text { Mean } \\
\text { body } \\
\text { weight } \\
(\mathrm{g})\end{array}$} & \multirow{2}{*}{$\begin{array}{c}\text { No. of } \\
\text { ovulated } \\
\text { animals }\end{array}$} & \multicolumn{2}{|c|}{ Ovulation } & \multirow[b]{2}{*}{$\begin{array}{l}\text { Position } \\
\text { of ova }\end{array}$} & \multirow[b]{2}{*}{$\begin{array}{l}\text { Vagina } \\
\text { opening }\end{array}$} \\
\hline & & & & & $\%$ & $\begin{array}{c}\text { No. of ova } \\
(\text { Mean } \pm \text { S.E. })\end{array}$ & & \\
\hline $\begin{array}{r}1 \\
2 \\
3 \\
4 \\
5 \\
6 \\
7 \\
8 \\
9 \\
10 \\
11 \\
12\end{array}$ & $\begin{array}{l}19 \\
20 \\
21 \\
22 \\
23 \\
24 \\
25 \\
26 \\
27 \\
28 \\
29 \\
31\end{array}$ & $\begin{array}{r}5 \\
10 \\
10 \\
10 \\
9 \\
10 \\
10 \\
10 \\
10 \\
11 \\
10 \\
10\end{array}$ & $\begin{array}{l}51 \cdot 0 \\
53 \cdot 0 \\
61 \cdot 0 \\
62 \cdot 5 \\
64 \cdot 9 \\
71 \cdot 5 \\
72 \cdot 9 \\
75 \cdot 8 \\
84 \cdot 0 \\
88 \cdot 1 \\
91 \cdot 4 \\
98 \cdot 6\end{array}$ & $\begin{array}{r}0 \\
0 \\
0 \\
4 \\
7 \\
10 \\
10 \\
10 \\
10 \\
11 \\
10 \\
10\end{array}$ & $\begin{array}{c}0 \\
0 \\
0 \\
40 \cdot 0 \\
77 \cdot 8 \\
100 \cdot 0 \\
100 \cdot 0 \\
100 \cdot 0 \\
100 \cdot 0 \\
100 \cdot 0 \\
100 \cdot 0 \\
100 \cdot 0\end{array}$ & $\begin{array}{c}0 \\
0 \\
0 \\
7 \cdot 2 \pm 1 \cdot 3 \\
8 \cdot 2 \pm 1 \cdot 0 \\
9 \cdot 0 \pm 1 \cdot 3 \\
9 \cdot 3 \pm 0 \cdot 9 \\
6 \cdot 6 \pm 0 \cdot 2 \\
9 \cdot 4 \pm 0 \cdot 8 \\
7 \cdot 0 \pm 1 \cdot 0 \\
11 \cdot 2 \pm 1 \cdot 2 \\
7 \cdot 7 \pm 0.7\end{array}$ & $\begin{array}{l}\text { Ampulla } \\
\text { Ampulla } \\
\text { Ampulla } \\
\text { Ampulla } \\
\text { Ampulla } \\
\text { Ampulla } \\
\text { Ampulla } \\
\text { Ampulla } \\
\text { Ampulla }\end{array}$ & $\begin{array}{l}- \\
- \\
- \\
+* \\
+* \\
+ \\
+ \\
+ \\
+ \\
+ \\
+ \\
+\end{array}$ \\
\hline
\end{tabular}

* Vaginal opening was observed only in those animals which had ovulated.

Forty per cent of the animals treated with 20 i.u. of HCG alone might be induced to ovulate twice within a period of $72 \mathrm{hr}$, i.e. the first ovulation occurring within $24 \mathrm{hr}$ of treatment and the second following within $48 \mathrm{hr}$ of the first. The results suggest that if the animals had pre-ovulatory follicles, HCG may cause ovulation and/or may stimulate a folliculogenesis in the immature ovary and advance the time of ovulation.

The second experiment was carried out on the ovulatory response of the immature rat to a single injection of HGG. Twelve groups of rats, aged from 19 to 
31 days, were treated as in the first experiment; they were killed $72 \mathrm{hr}$ after HCG treatment.

None of the animals aged from 19 to 21 days had ovulated $72 \mathrm{hr}$ after HCG, but ovulation was observed in all animals treated between the ages of 24 and 31 days, and all the eggs were located in the ampulla (Table 2).

Several explanations seem possible. HCG may directly stimulate the release of pituitary gonadotrophins. Alternatively, HGG may itself have FsH-like activity, or luteinizing activity which would provoke responsive follicles to produce the steroids which stimulate the release of pituitary FSH. The fact that ovulation can be induced only in rats above a certain age suggests that the maturity of the hypothalamo-pituitary axis may be important in regulating the release of gonadotrophins.

We would like to thank Dr C. E. Adams for much helpful criticism and advice.

\section{REFERENCES}

ADAMs, C. E. (1968) Ovarian response to human chorionic gonadotrophin and egg transport in the pregnant and post-parturient rabbit. F. Endocr. 40, 101.

Burdick, H. O. \& Ciampa, V. (1944) Further observations on induced ovulation in mice. A refractory period in early pregnancy. Endocrinology, 35, 473.

Greenwald, G. S. (1964) Ovarian follicular development in the pregnant hamster. Anat. Rec. 148, 605.

GREenwald, G. S. (1965) Histologic transformation of the ovary of the lactating hamster. Endocrinology, 77,641 .

Greenwald, G. S. (1966) Ovarian follicular development and pituitary FSH and LH content in the pregnant rat. Endocrinology, 79, 572.

Greenwald, G. S. (1967) Induction of ovulation in the pregnant hamster. Am. F. Anat. 121, 249.

McCoRmack, C. E. \& MeYer, R. K. (1962) Ovulating hormone release in gonadotrophin treated immature rats. Proc. Soc. exp. Biol. Med. 110, 343.

MCCormack, C. E. \& MEYER, R. K. (1968) Evidence for the release of ovulating hormone in PMStreated immature rats. Proc. Soc. exp. Biol. Med. 128, 18.

Mrtchell, J. A. \& Yochim, J. M. (1968) Relation of HCG-induced ovulation to the production of prolonged diestrus in the adult rat. Endocrinology, 82, 1142.

RowLAnds, I. W. (1956) The corpus luteum of the guinea-pig. Ciba Fdn Colloq. Ageing, 2, 69.

SAUNDERS, F. J. (1947) Induction of ovulation in the diestrus mouse by gonadotropins. Endocrinology, 40,1 .

Umezu, M., Kodama, C. \& Takeuchi, S. (1968) The effects of PMs or hCG on the ovulation in female immature rats. Tohoku J. agric. Res. 19, 50. 